\title{
Geochemistry of enclaves and host granites from the Nelas area, central Portugal
}

\author{
M.M.V.G. Silva ${ }^{\mathrm{a}, *}$, A.M.R. Neiva ${ }^{\mathrm{a}}$, M.J. Whitehouse ${ }^{\mathrm{b}, 1}$ \\ ${ }^{a}$ Department of Earth Sciences, Coimbra University, 3000 Coimbra, Portugal \\ ${ }^{\mathrm{b}}$ Department of Earth Sciences, University of Oxford, Oxford OX1 3PR, UK
}

Received 12 May 1998; accepted 5 August 1999

\begin{abstract}
Tonalitic, granodioritic and monzogranitic enclaves occur in the Hercynian peraluminous porphyritic biotite granite and biotite-muscovite granite from the Nelas region. Some variation diagrams show linear trends, but others show dispersion. The enclaves generally have closely similar isotopic signatures to those of the host granites. They contain xenocrystic plagioclase with the same composition as phenocrysts of the host granite, and have biotite as the sole ferromagnesian phase with a composition typically similar to that of the host granite. However, some cores of enclaves have biotite slightly chemically distinct from that of rims. The modelling of major and trace elements of granodioritic enclaves and hybrid host granite indicate that they result from simple mingling/mixing between a tonalitic magma and the host granite magma. Microgranular enclaves are thus interpreted to be globules of a more mafic magma probably from an enriched mantle source. Partial equilibration has been achieved between these enclaves and the host granite. (c) 2000 Elsevier Science B.V. All rights reserved.
\end{abstract}

Keywords: Enclaves; Granites; Geochemistry; Isotopes

\section{Introduction}

Different types of enclaves occur in granitic rocks and have been studied by several authors (e.g., Chappell et al., 1987; Chen et al., 1989; Dodge and Kistler, 1990; Didier and Barbarin, 1991; Barbarin and Didier, 1992; Elburg, 1996; Maas et al., 1997).

\footnotetext{
* Corresponding author

${ }^{1}$ Presently at Laboratory for Isotope Geology, Swedish Museum of Natural History, S-10405 Stockholm, Sweden.
}

The three main theories for the petrogenesis of microgranular enclaves interpret them as: (1) fragments of wallrock facies closely related to the host magma or of "cognate" fragments of cumulates; (2) globules of more mafic magma, generally hybrid magma, comingled with more felsic host magma, and (3) fragments of recrystallized, refractory metamorphic rocks and fragments of melt residues from the granite source as summarized by Maas et al. (1997). So clearly their origin remains controversial.

This paper presents the mineralogy, petrology, and major elements, trace element and $\mathrm{Sr}$ and $\mathrm{Nd}$ 
geochemistry of microgranular enclaves, xenoliths and host granites from the Nelas area, Central Portugal. The geochemical data are used to test specific magmatic processes which may have been involved in the genesis of the microgranular enclaves.

\section{Geological setting}

The Nelas area (Fig. 1a) is located within the Central Iberian Zone (CIZ) of the Iberian Massif which is one of the largest segments of the European

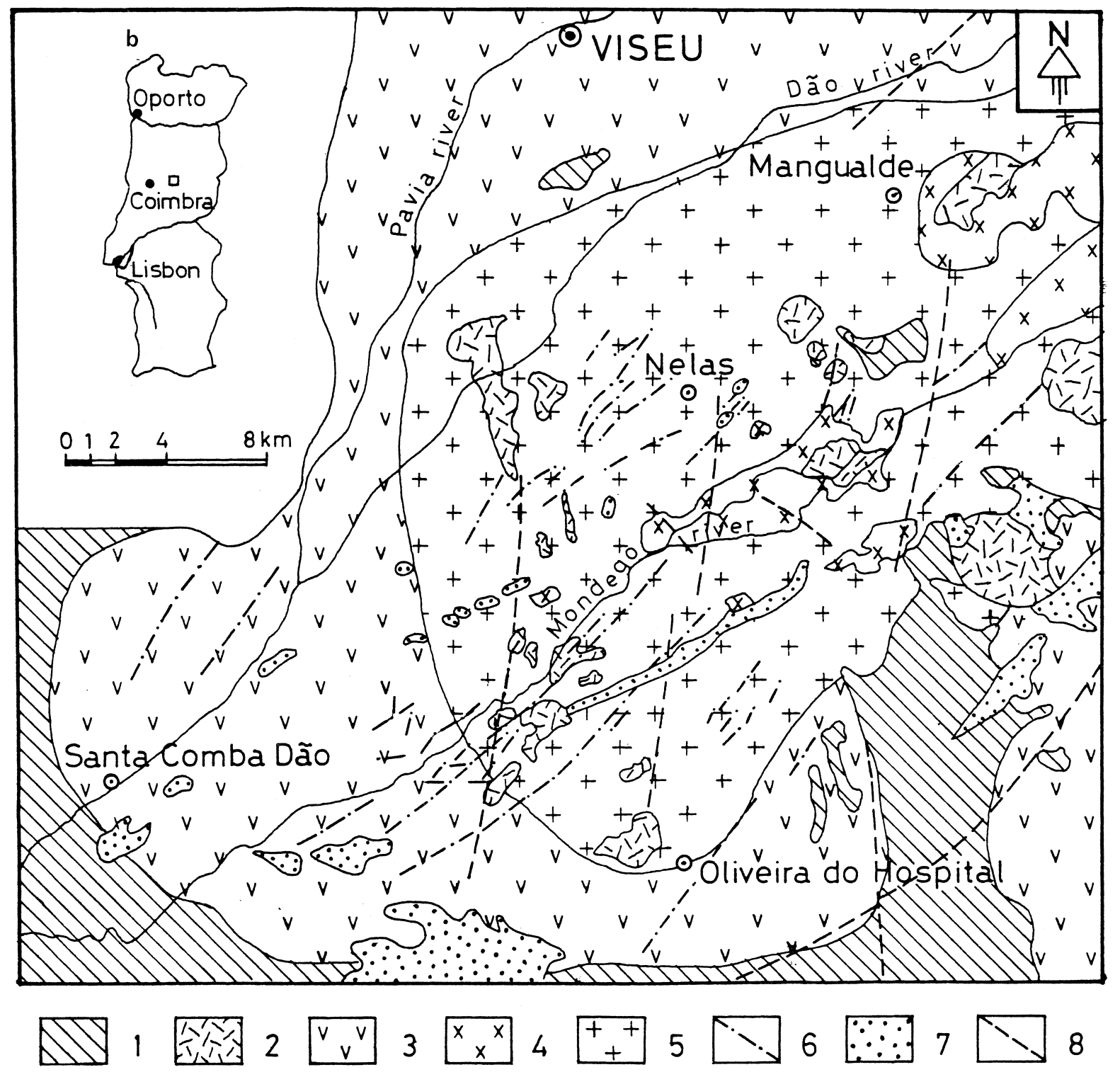

Fig. 1. (a) Geological map of Nelas area. (b) Location of the Nelas area in Portugal. 1 - Pre-Ordovician schist-metagraywacke complex; 2 - fine- to medium-grained muscovite-biotite granite; 3 - coarse- to very coarse-grained porphyritic biotite granite, 4 - medium- to fine-grained porphyritic biotite-muscovite granite, 5 - medium- to coarse-grained porphyritic biotite-muscovite granite, 6 - quartz veins; 7 - Meso-Cenozoic deposits; 8 - fault. 
Hercynian fold belt. This Massif resulted from the Variscan continent-continent collision from Late Devonian to Carboniferous (e.g., Matte, 1986). In the CIZ, three ductile deformation phases (D1, D2 and D3) have been recognized (Noronha et al., 1979) and also a fragile fourth deformation phase (D4) of Permian age (Pereira et al., 1993).

The CIZ Hercynian granitoids are classified according to their emplacement ages relative to the deformation phases as: (1) pre-orogenic, (2) syn-orogenic and (3) late to post-orogenic (e.g., Ferreira et al., 1987). Most of the CIZ granitoids post-date the syn-collisional stage of the Hercynian orogeny (D1 + D2) deformation phases and are related to D3 of the Namurian-Westphalian age. So the granitoids are classified as syn-, late- and late- to post-D3 granitoids (Ferreira et al., 1987).

The studied granites are located in Central Portugal and belong to the Beira batholith (Fig. 1b). The coarse- to very coarse-grained porphyritic biotite granite $(308 \pm 11 \mathrm{Ma})$ forms the border of the Beira batholith and is classified as a late-D3 granite. It passes gradationally through a transitional zone, showing decrease in grain size, increase in muscovite proportion and decrease in amount and size of phenocrysts, to a medium- to coarse-grained porphyritic biotite-muscovite granite ( $287 \pm 7 \mathrm{Ma})$, which crops out in the core of the batholith (Fig. 1a) and is classified as a late- to post-D3 granite. The phenocrysts show a magmatic flow alignment which is more pronounced close to the country rock contacts. In the biotite granite, phenocrysts reach $15 \times 10 \mathrm{~cm}$, while in the biotite-muscovite granite they generally reach $5 \times 3 \mathrm{~cm}$ and are less abundant.

The country rock is a metasedimentary sequence of Pre-Ordovician age, which consists of a chlorite phyllite with intercalations of metagraywacke, metasandstone and metaconglomerate. In Portugal, this formation is known as the Beira schistmetagraywacke complex (Fig. 1a).

The two granite magmas intruded this formation and the biotite granite produced a hornfels contact metamorphic aureole up to $150 \mathrm{~m}$ width, while close to the biotite-muscovite granite only mica-schist has been found probably because the country rock was hotter due to emplacement of the biotite granite and so, the temperature contrast between country rock and biotite-muscovite granite magma was not high enough to produce hornfels. The biotite-muscovite granite also intruded and surrounded the fine- to medium-grained muscovite-biotite granite and the medium- to fine-grained porphyritic biotite-muscovite granite. Aplite, pegmatite and quartz veins cut the batholith and the surrounding country rocks.

Both granites forming the border and core of the batholith contain xenoliths of metasedimentary origin and microgranular enclaves which commonly occur together. These are abundant close to the country rocks and in the transitional zone between both granites, but are rare within the interiors of each granite. Rare and small $(1-5 \mathrm{~cm})$ surmicaceous enclaves were also found in both granites.

The xenoliths rarely have diameters greater than $10 \mathrm{~cm}$, although larger examples occur. Their shapes are rounded and tabular and their contacts with the host granite are sharp. Some are fine-grained and massive, while others are fine- to medium-grained and schistose and occasionally show evidence of partial melting. They are very rich in micas.

Microgranular enclaves comprise up to $30 \%$ of a few outcrops. Their shapes are rounded or ovoid, but

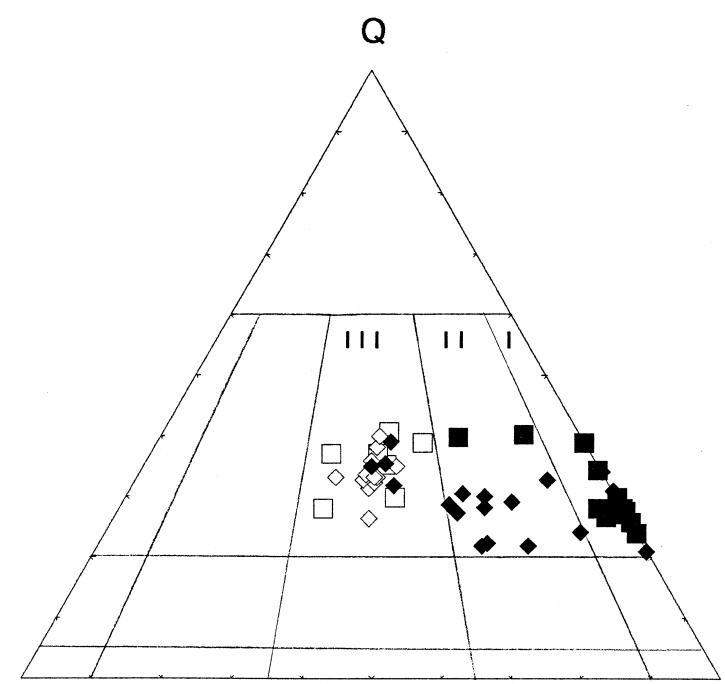

\section{A}

Fig. 2. Q-A-P diagram (Le Bas and Streckeisen, 1991) of microgranular enclaves and host granites from Nelas, central Portugal. Symbols: open - granites $(\square-$ biotite granite, $\diamond-$ biotitemuscovite granite); closed - microgranular enclaves in the respective granite. I - Tonalite, II — granodiorite, III - monzogranite. 


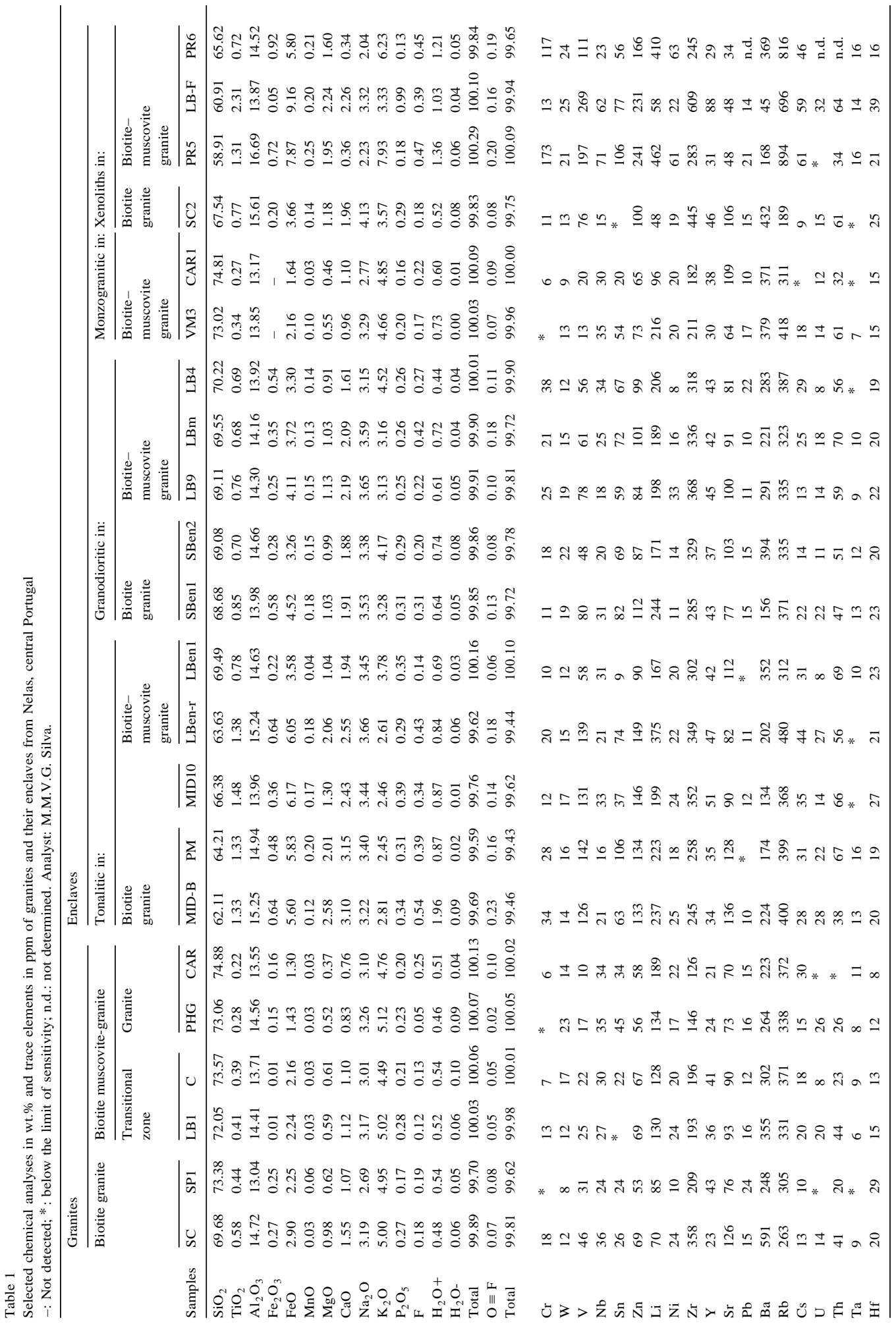


some are either irregular or fusiform. They are commonly $20-50 \mathrm{~cm}$ in diameter, but they range from 5 $\mathrm{cm}$ to $1.5 \mathrm{~m}$. The largest enclaves and also the fusiform enclaves occur in the transitional zone. The contacts of enclaves with host granites are sharp to diffuse and rarely show biotite concentration. Sharp contacts are more frequent amongst the rounded, smallest, darkest and finest-grained enclaves, which are commonly found within the biotite granite, but also occur in the biotite-muscovite granite. The largest enclaves are found in the biotite-muscovite granite. Enclaves partially enclose phenocrysts of the host granites and locally granite magma intruded enclave cores, suggesting the presence of two magmas in contact. The enclaves are fine-grained and darker than the host granites.

\section{Petrography}

\subsection{Granites}

Both granites are classified modally as monzogranites (Fig. 2) and have a porphyritic hypidiomorphic granular texture with microcline phenocrysts, but the biotite granite also contains phenocrysts of oligoclase-andesine. They contain quartz, alkalifeldspar, plagioclase, biotite, primary muscovite, tourmaline, monazite, apatite, zircon, ilmenite and rutile. Cordierite occurs only in the biotite granite. Secondary chlorite, sericite and calcite are rare.

Quartz is typically anhedral. The alkali-feldspar is perthitic microcline. The phenocrysts are euhedral, cross-hatched twinned and contain inclusions of plagioclase, quartz and biotite. In the biotite granite, biotite inclusions are concentrically distributed in microcline phenocrysts. Matrix alkali-feldspar is anhedral. The plagioclase phenocrysts in the biotite granite are euhedral and zoned from andesine cores to oligoclase rims. In both granites, matrix plagioclase is subhedral and zoned from andesine to near albite.

Biotite is generally subhedral, pleochroic from $\beta$-reddish-brown to $\alpha$-pale yellow and contains inclusions of zircon, apatite, ilmenite and monazite. Locally, biotite is altered to chlorite. Muscovite occurs in both granites, but it is very rare in the biotite granite. It is subhedral, locally intergrown with biotite and its size is similar to that of the other minerals of the matrix. So the texture indicates that it is primary muscovite and its composition is similar to that of primary muscovite from Miller et al. (1981).

Cordierite occurs only in the biotite granite. It is euhedral, prismatic, with a similar grain size to that of matrix feldspars. It has no inclusions and generally is altered to pinnite. Apatite is euhedral and prismatic. Monazite is euhedral and zoned. Zircon is zoned with rounded cores and euhedral rims in the biotite granite. Tourmaline (schorl) is zoned and probably late-magmatic. Rutile occurs as inclusions in biotite and quartz and is also associated with chloritization of biotite.

\subsection{Microgranular enclaves}

The microgranular enclaves are classified modally as tonalites, granodiorites and monzogranites (Fig. 2 ). The very fine- to fine-grained tonalitic enclaves are more common in the biotite granite, while the fine- to medium-grained granodioritic and monzogranitic enclaves mainly occur in the biotitemuscovite granite.

The tonalitic enclaves have hypidiomorphic-allotriomorphic textures, some with plagioclase phe-

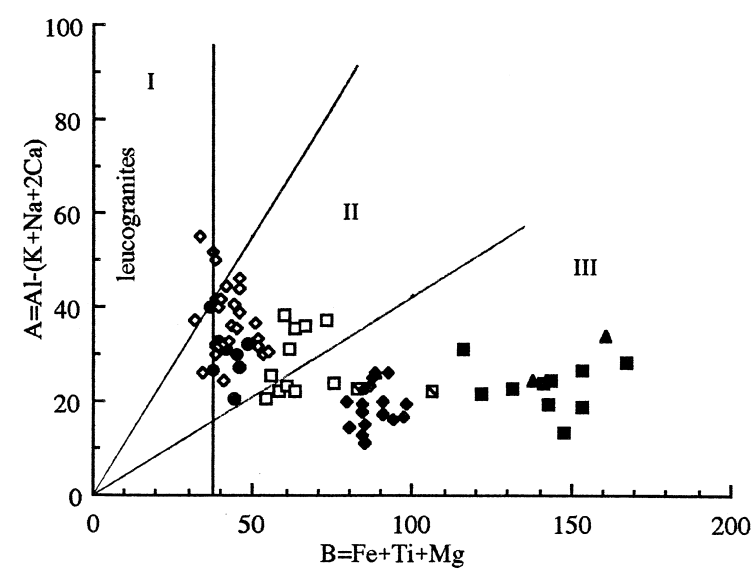

Fig. 3. (A,B) Diagram (Debon and Le Fort, 1982) of microgranular enclaves and host granites from Nelas, central Portugal. Symbols: for granites as in Fig. 2; microgranular enclaves in: (a) biotite granite - tonalite, (square with diagonal line) granodiorite; (b) biotite-muscovite granite $\Delta-$ tonalite, granodiorite, - monzogranite. Fields: I - muscovite $>$ biotite, II - biotite $>$ muscovite and III - biotite. 

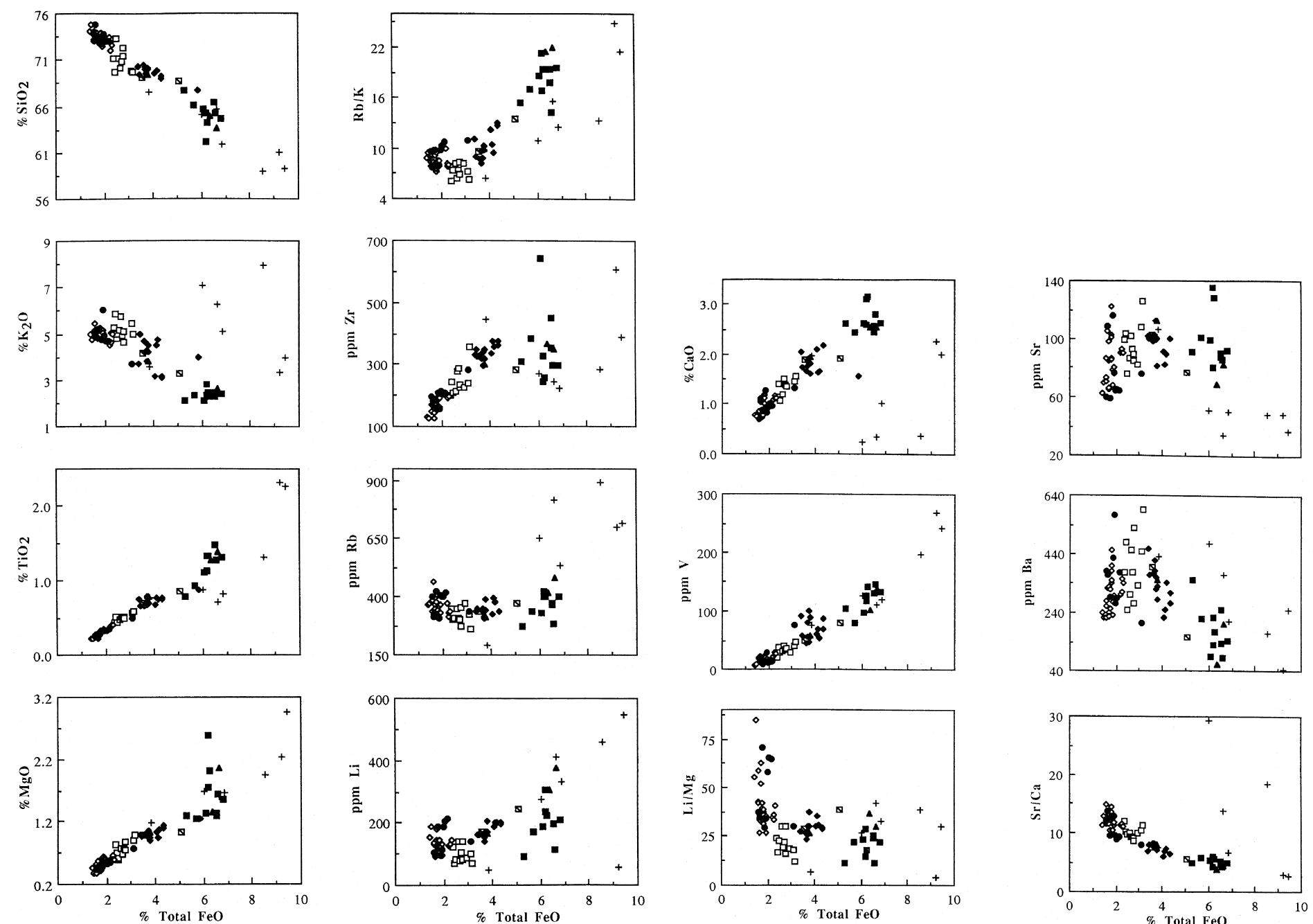

Fig. 4. Variation diagrams for selected major and trace elements and ratios of enclaves and host granites from Nelas, central Portugal. Symbols: as in Fig. $3,+-$ xenoliths. 
nocrysts and plagioclase and quartz megacrysts. The matrix is formed by laths of plagioclase and biotite, interstitial or poikilitic quartz, rare orthoclase, apatite, zircon, ilmenite and rutile. The granodioritic and monzogranitic enclaves have hypidiomorphic textures, with plagioclase and microcline phenocrysts. The matrix is formed by plagioclase, biotite, quartz, microcline, apatite, zircon, ilmenite and rutile.

Quartz is anhedral, a late crystallizing, interstitial or poikilitic phase in some tonalitic enclaves. Quartz megacrysts are rounded, and much larger than other crystals in enclaves. Locally, these megacrysts form concentrations and the crystals have a zone of biotite inclusions close to the rim. The alkali-feldspar is orthoclase in the tonalitic enclaves and microcline in granodioritic and monzogranitic enclaves. Some microcline megacrysts are rimmed by plagioclase crystals which are thought to reflect magma mixing (Hibbard, 1991).

The plagioclase phenocrysts are euhedral to subhedral and show pronounced zoning. In some tonalitic enclaves, phenocrysts have a labradorite-andesine core separated from an andesine-oligoclase rim by a discontinuity corresponding to a reaction surface. Other tonalitic enclaves and granodioritic enclaves contain andesine-oligoclase phenocrysts. The matrix plagioclase is subhedral to anhedral, zoned and of a uniform grain size; its composition ranges from andesine in the tonalitic enclaves to albite in monzogranitic enclaves. The plagioclase megacrysts found in tonalitic enclaves are larger than the respective plagioclase phenocrysts and the composition is similar to that of plagioclase phenocrysts in the host granite.

Biotite of microgranular enclaves is generally very similar to the biotite of the host granite. It contains inclusions of zircon, apatite and ilmenite. However, in the tonalitic enclaves, the biotite has a very fine and uniform grain size and does not contain inclusions, but there are also some aggregates of crystals which have a similar grain size to the biotite of the host granite. Tonalitic and granodioritic enclaves have higher modal biotite content $(15-29 \%)$ than the host biotite granite $(8-14 \%)$ and biotite-muscovite granite $(4-7 \%)$, but monzogranitic enclaves have similar modal biotite contents $(4-7 \%)$ to that of their host biotite-muscovite granite.
Apatite is euhedral and prismatic, but in the tonalitic enclaves there is also acicular apatite, which is considered to result from rapid cooling (Wyllie et al., 1962). Zircon occurs only in the granodioritic and monzogranitic enclaves. Inclusions of rutile were found in quartz.

\subsection{Xenoliths}

There are two types of xenoliths: (1) very finegrained, massive, hornfelses with a granolepidoblas-
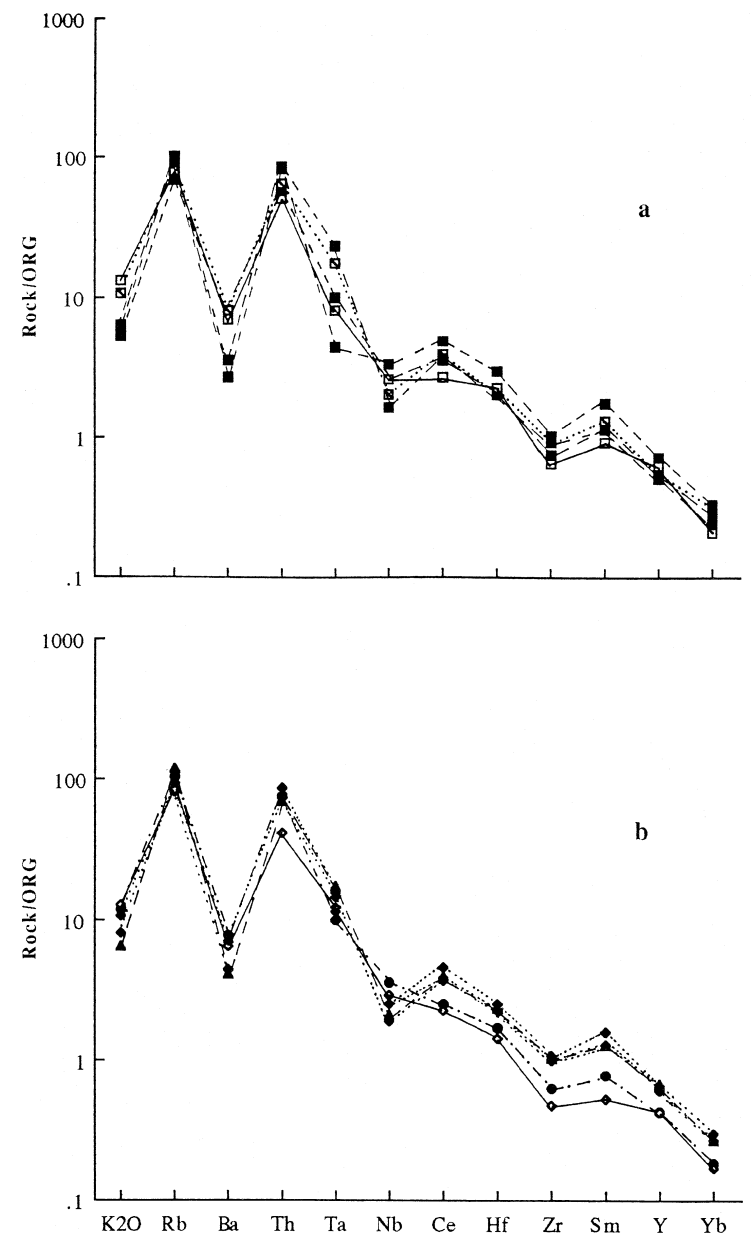

Fig. 5. Normalized trace element abundance patterns of microgranular enclaves and host granites from Nelas, central Portugal. Symbols: as in Fig. 3, (a) biotite granite, -.... tonalitic enclaves, $\cdots \cdots$ granodioritic enclaves; (b) biotite-muscovite granite, - - - -- tonalitic enclaves, $\cdots \cdots$ granodioritic enclaves; ...... monzogranitic enclave. ORG hypothetical ocean ridge granite of Pearce et al. (1984). 


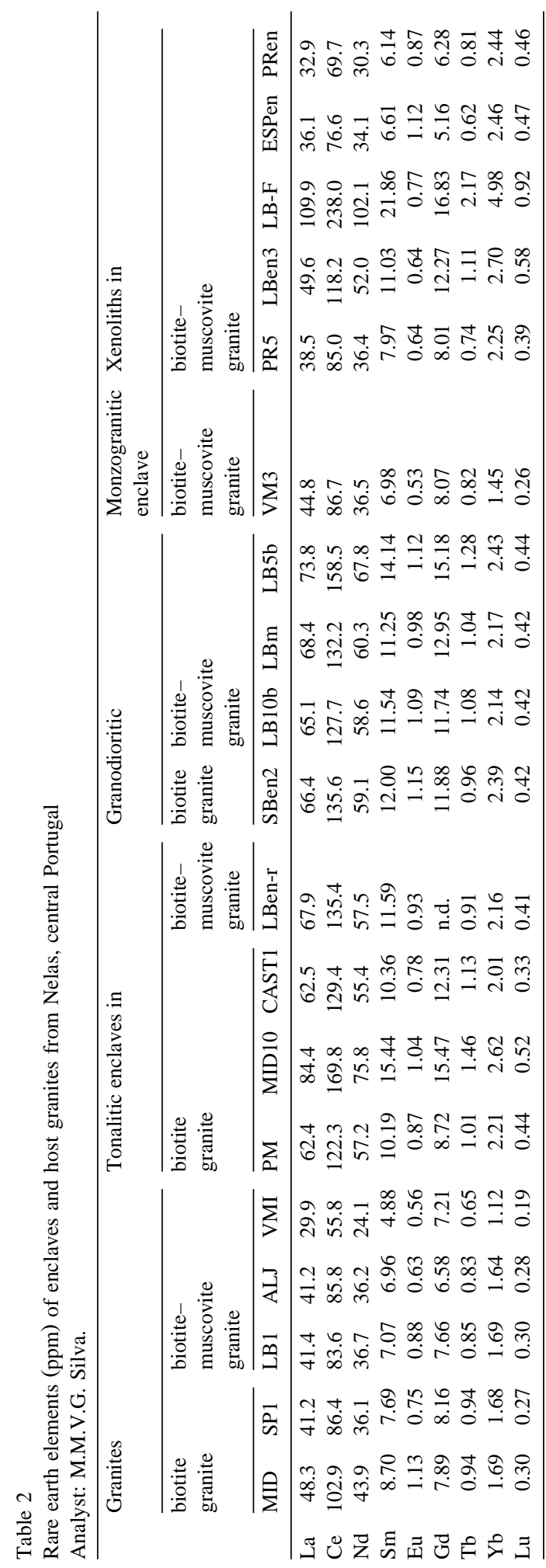

tic texture and (2) fine- to medium-grained, foliated micaschists, with lepidoblastic texture. Both types have similar mineralogical compositions containing quartz $(29-32 \%)$, biotite $(15-35 \%)$, plagioclase (6$28 \%)$, microcline $(7-26 \%)$ and muscovite $(1-12 \%)$. The accessory minerals are commonly apatite, ilmenite and zircon. However, cordierite $(1.5 \%)$ and rare sillimanite were also found in a xenolith which occurs in the biotite granite and andalusite $(0.5 \%)$ was found in a xenolith occurring in the biotitemuscovite granite.

Quartz is anhedral and shows weakly undulose extinction. Slightly perthitic microcline and oligoclase-albite are subhedral to anhedral. Biotite is subhedral, pleochroic from $\beta$-reddish-brown to $\alpha$ pale yellow and contains rare zircon and apatite inclusions. Fibrolite occurs associated with biotite, while anhedral andalusite is associated with muscovite. Cordierite is anhedral and fine-grained.

\section{Analytical methods}

Major and trace element compositions of rocks were determined by XRF at Manchester University, UK, using the method of Brown et al. (1973). The precision is $\pm 1 \%$ for major elements and $\mathrm{Rb}$; for other trace elements it is $\pm 4 \%$ and the detection limit is about $5 \mathrm{ppm}$. The major element compositions of minerals were determined with a modified Cambridge Geoscan electron microprobe with Link Systems energy-dispersive system at Manchester University and a Cameca Camebax at Instituto Geológico e Mineiro, Portugal. The results show good agreement between the two laboratories and the precision is $\pm 5 \%$.

$\mathrm{FeO}, \mathrm{H}_{2} \mathrm{O}+, \mathrm{F}$ and $\mathrm{Li}$ were determined at the Department of Earth Sciences, Coimbra University. $\mathrm{FeO}$ contents were determined by titration with a standardised potassium permanganate solution with precision of $\pm 1 \%$. The $\mathrm{H}_{2} \mathrm{O}+$ was determined using a Penfield tube and the precision is $\pm 5 \%$. $\mathrm{F}$ was determined by selective ion electrode analysis with a precision of $\pm 10 \%$. Li was determined by atomic absorption with a precision of $\pm 2 \%$. Rare earth elements were determined by neutron activation analysis with a precision of $\pm 5 \%$ at the Imperial College Reactor Centre, Ascot, UK. 
$\mathrm{Rb}-\mathrm{Sr}$ and $\mathrm{Sm}-\mathrm{Nd}$ isotopes were analysed in the Department of Earth Sciences, Oxford University, UK, using techniques similar to those described by Whitehouse (1990). Sr isotopes were measured using a VG-Micromass 30 mass spectrometer and the maximum uncertainty in ${ }^{87} \mathrm{Sr} /{ }^{86} \mathrm{Sr}$ was $\pm 0.00005(2 \sigma)$. The uncertainty in $\mathrm{Rb} / \mathrm{Sr}$ (determined by XRF) was $\pm 1 \%$. The $\mathrm{Sm}-\mathrm{Nd}$ isotopes were measured with a VG 54E mass spectrometer and corrected for mass fractionation effects to ${ }^{146} \mathrm{Nd} /{ }^{144} \mathrm{Nd}=0.7219$. The uncertainties on ${ }^{143} \mathrm{Nd} /{ }^{144} \mathrm{Nd}$ were lower than $0.0025 \%(2 \sigma)$. The uncertainties in ${ }^{147} \mathrm{Sm} /{ }^{144} \mathrm{Nd}$ (determined by isotope dilution) was $\pm 0.1 \%$.
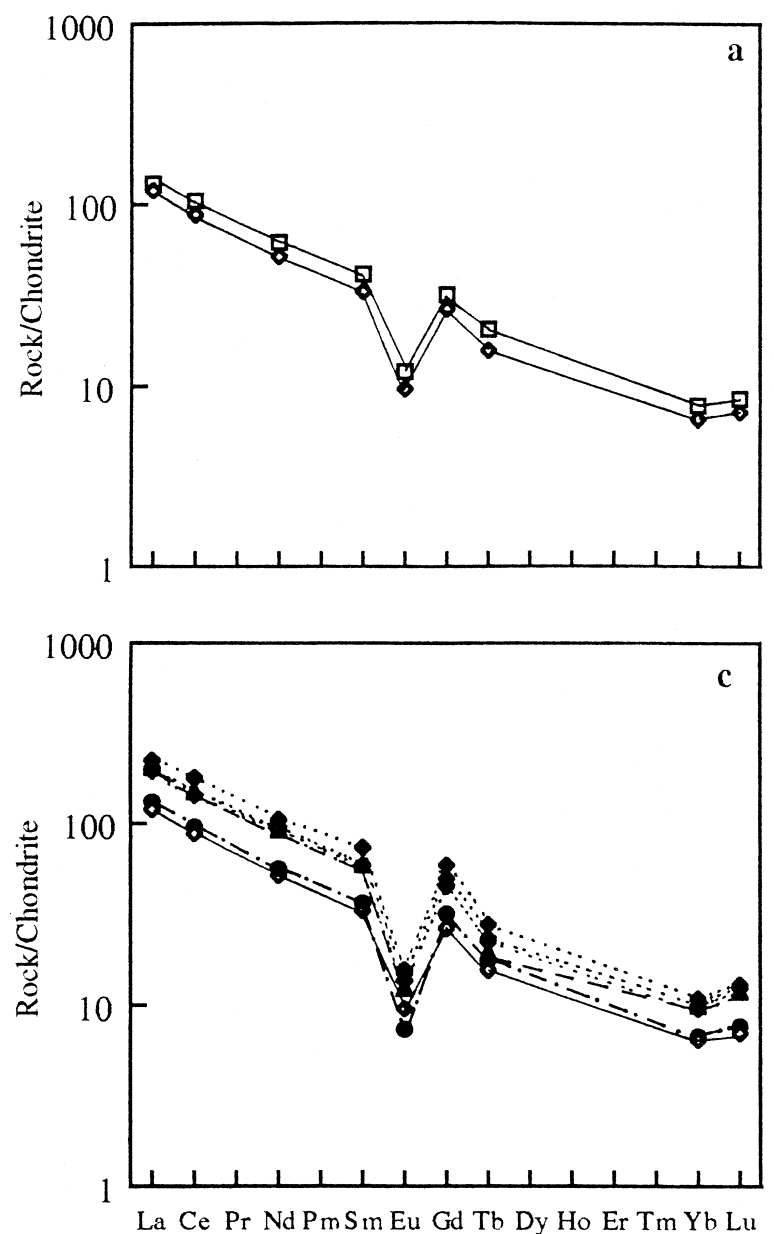

\section{Whole rock geochemistry}

\subsection{Major and trace elements}

Representative whole rock analyses are given in Table 1. Granites and enclaves are both peraluminous. Molecular A/CNK ratio ranges from 1.08 to 1.16 in the biotite granite and from 1.10 to 1.25 in the biotite-muscovite granite. The enclaves have A/CNK values (1.04-1.17) similar to or slightly lower than that of the respective host granite and they form an aluminous association (Fig. 3). The
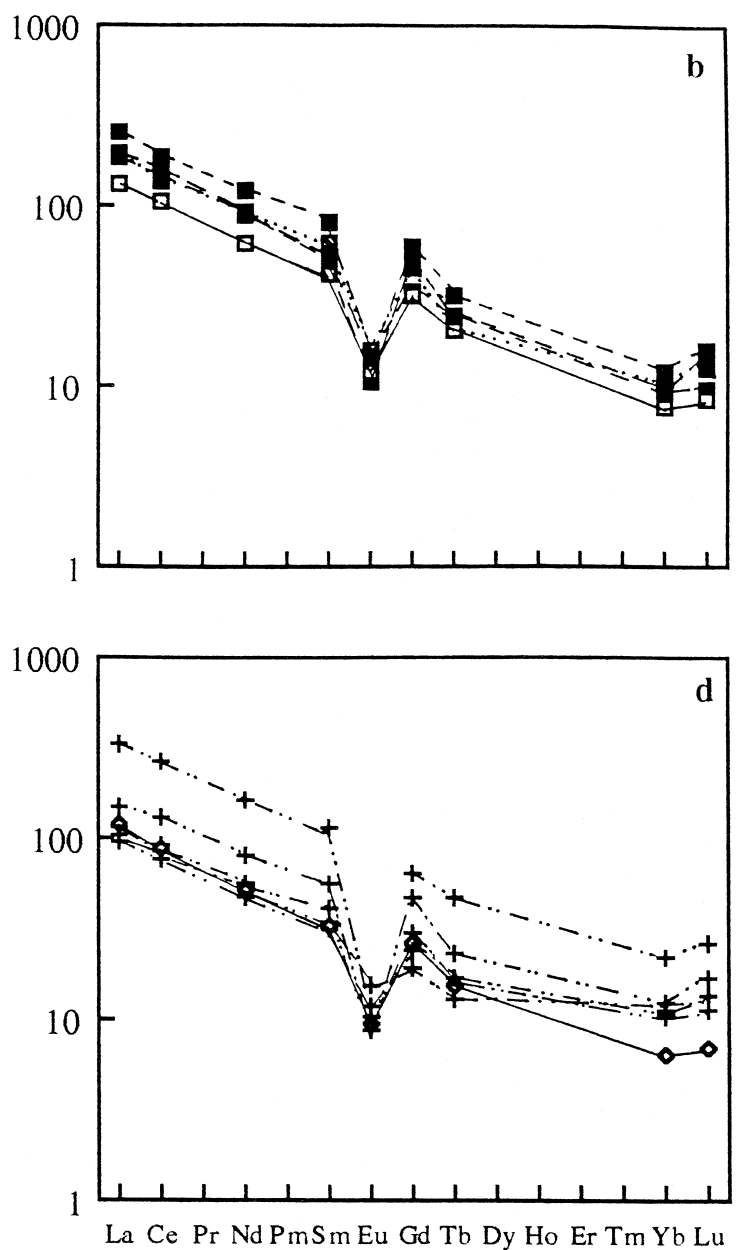

Fig. 6. Chondrite-normalized REE abundances of selected enclaves and host granites from Nelas, central Portugal. (a) Host granites; (b) biotite granite and its microgranular enclaves; (c) biotite-muscovite granite and its microgranular enclaves; (d) biotite-muscovite granite and its xenoliths. Symbols: as in Fig. 3. xenoliths. Chondrite abundances (Haskin et al., 1968). 
monzogranitic enclaves have compositions similar to that of the host granite, but very different from those of the other enclaves.

Total $\mathrm{FeO}$ has been chosen as abscissa for the variation diagrams, because it separates these granitic rocks better than $\mathrm{SiO}_{2}$ does. The two granites define a sequence (Fig. 4). For $\mathrm{SiO}_{2}, \mathrm{~K}_{2} \mathrm{O}, \mathrm{TiO}_{2}, \mathrm{MgO}$, $\mathrm{CaO}, \mathrm{V}, \mathrm{Sr} / \mathrm{Ca}$ and $\mathrm{Rb} / \mathrm{K}$, the tonalitic and granodioritic enclaves lie on an extension of the host granite trends, while monzogranitic enclaves plot very close to the host granite. Unlike the host granite the microgranular enclaves do not show any clear trend for most trace elements and trace/major element ratios. Furthermore, these enclaves have similar $\mathrm{Rb}, \mathrm{Li}, \mathrm{Sr}$, $\mathrm{Ba}$ and $\mathrm{Li} / \mathrm{Mg}$ values, but generally lower $\mathrm{Sr} / \mathrm{Ca}$ and higher $\mathrm{Rb} / \mathrm{K}$ than the host granites (Fig. 4).

The xenoliths (metasedimentary enclaves) are richer in $\mathrm{Rb}$ and $\mathrm{Cs}$ and poorer in $\mathrm{Sr}$ than the microgranular enclaves and host granites and generally they fall outside the defined trends (Table 1 and Fig. 4).

Normalized geochemical patterns for microgranular enclaves and host granites are plotted in Fig. 5. The normalizing factor is the hypothetical ocean ridge granite (ORG) of Pearce et al. (1984). These patterns have positive $\mathrm{Rb}$, Th and $\mathrm{Sm}$ anomalies and negative $\mathrm{Ba}$ and $\mathrm{Zr}$ anomalies suggesting that host granites and microgranular enclaves have a dominantly crustal origin. However, values of $\mathrm{Hf}, \mathrm{Zr}, \mathrm{Sm}$ and $\mathrm{Y}$ are close to the normalizing value which could indicate a contribution from mantle components in the source rock.

\section{2. $R E E$}

Representative REE contents of enclaves and host granites are given in Table 2. There is a decrease in

Table 3

$\mathrm{Rb}-\mathrm{Sr}$ isotopic analyses of enclaves and host granites from Nelas, central Portugal

$\left({ }^{87} \mathrm{Sr} /{ }^{86} \mathrm{Sr}\right)_{0}$ in enclaves and host granites have been calculated for the ages yielded by the $\mathrm{Rb}-\mathrm{Sr}$ isochrons for granites. Analyst: M.M.V.G. Silva.

\begin{tabular}{|c|c|c|c|c|c|c|c|c|}
\hline & Samples & $\mathrm{Rb}(\mathrm{ppm})$ & $\mathrm{Sr}(\mathrm{ppm})$ & $\mathrm{Rb} / \mathrm{Sr}$ & ${ }^{87} \mathrm{Rb} /{ }^{86} \mathrm{Sr}$ & ${ }^{87} \mathrm{Sr} /{ }^{86} \mathrm{Sr}$ & \pm Error & $\left({ }^{87} \mathrm{Sr} /{ }^{86} \mathrm{Sr}\right)_{0}$ \\
\hline \multirow[t]{6}{*}{ Biotite granite } & SC & 263.2 & 125.9 & 2.087 & 6.125 & 0.73384 & 0.00004 & 0.7070 \\
\hline & LI & 300.8 & 104.3 & 2.944 & 8.648 & 0.74431 & 0.00002 & 0.7064 \\
\hline & CAST & 304.1 & 92.6 & 3.371 & 9.907 & 0.75009 & 0.00004 & 0.7067 \\
\hline & SB1 & 351.3 & 87.3 & 4.137 & 12.171 & 0.76075 & 0.00005 & 0.7074 \\
\hline & $\mathrm{F}$ & 269.5 & 89.4 & 3.105 & 9.123 & 0.74697 & 0.00005 & 0.7070 \\
\hline & SP1 & 304.7 & 75.6 & 4.193 & 12.336 & 0.76046 & 0.00005 & 0.7064 \\
\hline \multirow[t]{6}{*}{ Biotite-muscovite granite } & LB1 & 331.0 & 92.7 & 3.664 & 10.774 & 0.75550 & 0.00004 & 0.7115 \\
\hline & $\mathrm{PH}$ & 337.5 & 73.1 & 5.270 & 15.526 & 0.77489 & 0.00002 & 0.7115 \\
\hline & ANDI & 335.4 & 86.2 & 4.007 & 11.787 & 0.75926 & 0.00005 & 0.7111 \\
\hline & $\mathrm{CF} 4$ & 377.5 & 58.9 & 6.787 & 20.031 & 0.79337 & 0.00004 & 0.7116 \\
\hline & VM & 364.4 & 66.0 & 5.792 & 17.074 & 0.78099 & 0.00004 & 0.7113 \\
\hline & CAR & 372.4 & 69.9 & 5.559 & 16.384 & 0.77882 & 0.00003 & 0.7119 \\
\hline \multicolumn{9}{|l|}{ Enclaves in biotite granite } \\
\hline \multirow[t]{6}{*}{ Tonalitic } & MID-B & 395.4 & 138.0 & 2.880 & 8.459 & 0.74314 & 0.00004 & 0.7061 \\
\hline & PM & 399.4 & 127.5 & 3.159 & 9.281 & 0.74592 & 0.00005 & 0.7052 \\
\hline & MID4 & 398.5 & 92.4 & 4.416 & 12.994 & 0.76238 & 0.00004 & 0.7054 \\
\hline & $\mathrm{SC} 3$ & 286.7 & 86.3 & 3.427 & 10.073 & 0.75060 & 0.00005 & 0.7065 \\
\hline & MID11 & 330.5 & 99.2 & 3.404 & 10.006 & 0.75194 & 0.00004 & 0.7081 \\
\hline & MID10 & 367.7 & 90.4 & 4.173 & 12.279 & 0.76224 & 0.00005 & 0.7084 \\
\hline Granodioritic & SBen1 & 371.0 & 77.4 & 4.968 & 14.632 & 0.77147 & 0.00003 & 0.7073 \\
\hline \multicolumn{9}{|c|}{ Enclaves in biotite-muscovite granite } \\
\hline Tonalitic & LBen1 & 311.7 & 111.9 & 2.832 & 8.319 & 0.74446 & 0.00003 & 0.7105 \\
\hline Granodioritic & LBen & 308.0 & 112.4 & 2.785 & 8.181 & 0.74506 & 0.00003 & 0.7117 \\
\hline \multirow[t]{2}{*}{ Xenoliths } & PR5 & 893.6 & 48.3 & 19.86 & 59.592 & 0.96521 & 0.00005 & 0.7219 \\
\hline & $\mathrm{LBF}$ & 695.9 & 47.5 & 15.77 & 47.053 & 0.90610 & 0.00003 & 0.7139 \\
\hline
\end{tabular}


all REE and a slight increase in the negative $\mathrm{Eu}$ anomaly from the biotite granite to the biotitemuscovite granite and their patterns are sub-parallel (Table 2; Fig. 6a).

The microgranular enclaves generally have higher contents of all REE, higher $(\mathrm{La} / \mathrm{Yb})_{N}$ and similar or slightly larger negative $\mathrm{Eu}$ anomalies than the respective host granite and their patterns are subparallel (Fig. 6b,c). There is a general decrease in all REE from the tonalitic to monzogranitic enclaves and from these to the host granites.

REE are mainly concentrated in apatite, monazite and zircon. There is a decrease in $\mathrm{P}_{2} \mathrm{O}_{5}, \mathrm{Y}$ and $\mathrm{Zr}$ contents from biotite granite to biotite-muscovite granite and also from microgranular enclaves to the respective host granite.

The REE patterns of xenoliths cut those of the host granite in the HREE (Fig. 6d). They are less enriched in LREE with respect to HREE than the host granites, as confirmed by $(\mathrm{La} / \mathrm{Yb})_{N}$ and $(\mathrm{La} / \mathrm{Lu})_{N}$ ratios.

\subsection{Isotope geochemistry}

$\mathrm{Rb}-\mathrm{Sr}$ isotopic data are given in Table 3. The biotite granite yields a $\mathrm{Rb}-\mathrm{Sr}$ isochron of $308 \pm 11$ Ma, with a MSWD $=0.965$, while the biotitemuscovite granite yields another $\mathrm{Rb}-\mathrm{Sr}$ isochron of $287 \pm 7 \mathrm{Ma}$, with a MSWD $=0.551$ and together they yield a common errochron of $305 \pm 11 \mathrm{Ma}$, with a MSWD $=3.61$. Each isochron was defined with six points, whose data are given in Table 3 . The ages of these two granites are not very different if the errors are taken into account. $\mathrm{A}\left({ }^{87} \mathrm{Sr} /{ }^{86} \mathrm{Sr}\right)_{0}$ of $0.7068 \pm 0.0015$ was found for the biotite granite, while $\left({ }^{87} \mathrm{Sr} /{ }^{86} \mathrm{Sr}\right)_{0}$ was $0.7115 \pm 0.0016$ for the biotite-muscovite granite (Silva and Neiva, in press). The biotite-muscovite granite would have been derived from the biotite granite by an AFC mechanism and the assimilated material would have $\left({ }^{87} \mathrm{Sr} /{ }^{86} \mathrm{Sr}\right)_{0}$ $=0.73$ (Silva and Neiva, in press).

In the ${ }^{87} \mathrm{Rb} /{ }^{86} \mathrm{Sr}$ versus ${ }^{87} \mathrm{Sr} /{ }^{86} \mathrm{Sr}$ diagram, the microgranular enclaves plot close to the host granite isochrons (Fig. 7a and b). The $\left({ }^{87} \mathrm{Sr} /{ }^{86} \mathrm{Sr}\right)_{0}$ of each enclave was calculated assuming that its age is identical to that of the host granite (Table 3). The microgranular enclaves have generally $\left({ }^{87} \mathrm{Sr} /{ }^{86} \mathrm{Sr}\right)_{0}$ values close or in the range of that for the respective host granite, suggesting a granite-enclave interaction (Fourcade and Javoy, 1991; Stephens et al., 1991).

The microgranular enclaves have lower ${ }^{147} \mathrm{Sm} /{ }^{144}$ $\mathrm{Nd}$ ratio and similar or lower $T_{\mathrm{DM}}$ ages compared to the respective host granites (Table 4). They have negative $\varepsilon_{\mathrm{Nd}} T$ values, which agree with the data of Fourcade and Javoy (1991), Cocherie et al. (1994), Dias and Leterrier (1994), Elburg (1996) and Maas et al. (1997) for enclaves, host granites and associated basic rocks. The plot of $\varepsilon_{\mathrm{Nd}}(T)$ versus initial ${ }^{87} \mathrm{Sr} /{ }^{86} \mathrm{Sr}$ ratio (Fig. 8) suggests that microgranular enclaves equilibrated with a large volume of host granite magma.
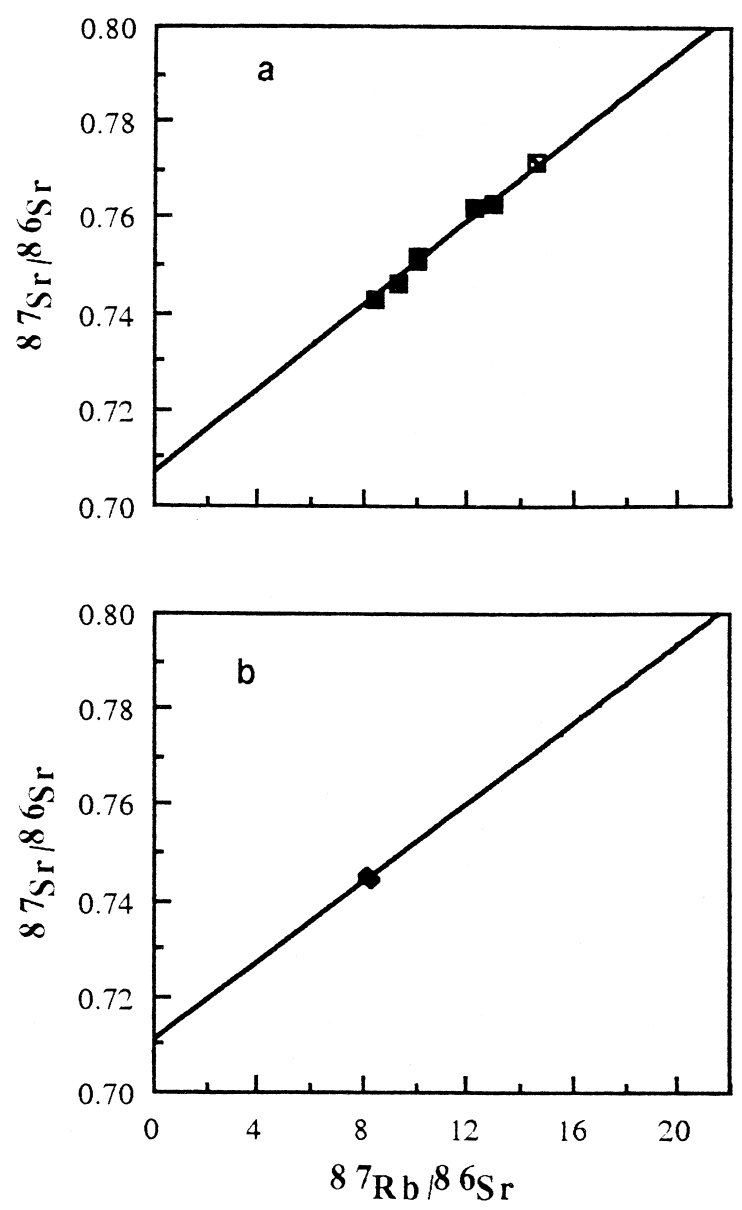

Fig. 7. Plot of microgranular enclaves and whole-rock $\mathrm{Rb}-\mathrm{Sr}$ isochron for the respective host granites from Nelas, central Portugal. (a) Biotite granite, (b) biotite-muscovite granite. Symbols as in Fig. 3. 
Table 4

$\mathrm{Sm}-\mathrm{Nd}$ isotopic analyses of microgranular enclaves and host granites from Nelas, central Portugal

$\varepsilon_{\mathrm{Nd}}$ values and $T_{\mathrm{DM}}$ ages were calculated based on values of Jacobsen and Wasserburg (1984) and De Paolo (1981), respectively.

Analyst: M.J. Whitehouse.

\begin{tabular}{|c|c|c|c|c|c|c|c|c|c|c|c|}
\hline & & $\mathrm{Sm}(\mathrm{ppm})$ & $\mathrm{Nd}(\mathrm{ppm})$ & $\mathrm{Sm} / \mathrm{Nd}$ & ${ }^{147} \mathrm{Sm} /{ }^{144} \mathrm{Nd}$ & ${ }^{143} \mathrm{Nd} /{ }^{144} \mathrm{Nd}$ & $\pm(\%)$ & $\left({ }^{143} \mathrm{Nd} /{ }^{144} \mathrm{Nd}\right)_{0}$ & $\varepsilon_{\mathrm{Nd}}$ & $\varepsilon_{\mathrm{Nd}}(T)$ & $T_{\mathrm{DM}}$ \\
\hline \multicolumn{12}{|c|}{ Biotite granite } \\
\hline & $\mathrm{SC}$ & 8.338 & 42.890 & 0.1944 & 0.1175 & 0.512330 & 0.0019 & 0.512093 & -6.0 & -2.9 & 1.1 \\
\hline & SP1 & 7.073 & 33.449 & 0.2115 & 0.1278 & 0.512325 & 0.0018 & 0.512067 & -6.1 & -3.4 & 1.3 \\
\hline \multicolumn{12}{|c|}{ Biotite-muscovite granite } \\
\hline & LB1 & 6.726 & 33.275 & 0.2021 & 0.1222 & 0.512268 & 0.0020 & 0.512038 & -7.2 & -4.5 & 1.3 \\
\hline & VM & 5.106 & 24.683 & 0.2069 & 0.1250 & 0.512240 & 0.0023 & 0.512005 & -7.8 & -5.2 & 1.4 \\
\hline \multicolumn{12}{|c|}{ Tonalitics (ton) and granodioritics (gran) enclaves in biotite granite } \\
\hline (ton) & Mid4 & 9.129 & 48.244 & 0.1892 & 0.1144 & 0.512235 & 0.0019 & 0.512004 & -7.9 & -4.6 & 1.2 \\
\hline (gran) & SBen1 & 10.662 & 57.257 & 0.1862 & 0.1126 & 0.512217 & 0.0018 & 0.51199 & -8.2 & -4.9 & 1.2 \\
\hline \multicolumn{12}{|c|}{ Tonalitics (ton) and granodioritics (gran) enclaves in biotite - muscovite granite } \\
\hline (ton) & LBen1 & 12.032 & 63.983 & 0.1880 & 0.1137 & 0.512263 & 0.0020 & 0.512049 & -7.3 & -4.3 & 1.2 \\
\hline (gran) & LBen & 12.868 & 70.851 & 0.1816 & 0.1098 & 0.512229 & 0.0024 & 0.512023 & -8.0 & -4.8 & 1.2 \\
\hline
\end{tabular}




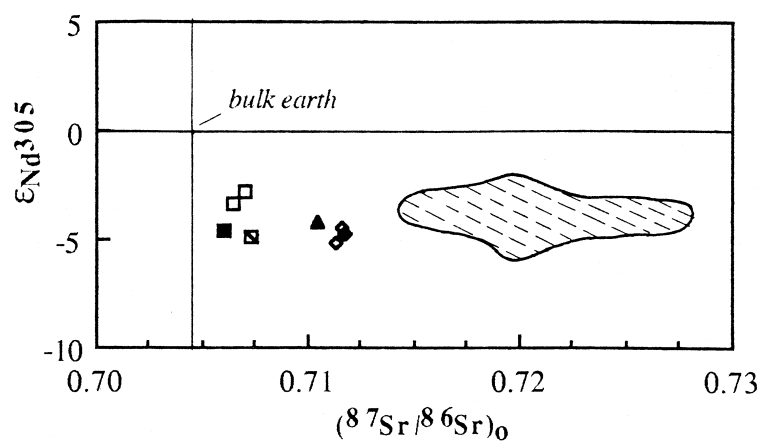

Fig. 8. $\left({ }^{87} \mathrm{Sr} /{ }^{86} \mathrm{Sr}\right)_{0}$ versus $\varepsilon_{\mathrm{Nd}}(T)$ for microgranular enclaves and host granites from Nelas, central Portugal. Symbols as in Fig. 3. The shaded area corresponds to the metasedimentary protolith of Portuguese Hercynian granites (Beetsma, 1995).

The xenoliths have higher initial ${ }^{87} \mathrm{Sr} /{ }^{86} \mathrm{Sr}$ ratios than those of the host granite and microgranular enclaves (Table 3).

\section{Geochemistry of minerals}

\subsection{Feldspars}

Compositions of alkali-feldspar and plagioclase are given in Table 5. The Or content of matrix K-rich feldspar is similar to or higher than that of the respective phenocryst alkali-feldspar. The matrix alkali-feldspar of enclaves has a similar Or content to that of phenocryst alkali-feldspar, but similar or lower Or content than that of matrix alkali-feldspar of the host granite. Generally, phenocryst and matrix plagioclase of enclaves has similar or higher anorthite content than that of the respective plagioclase of host granite. In single crystals, the cores are richer in anorthite content than the respective rims. Anorthite content decreases in plagioclase from tonalitic enclaves to monzogranitic enclaves.

Plagioclase megacrysts were found only in some tonalitic enclaves of the biotite granite. They are of larger size and lower anorthite content than the respective phenocrysts, but similar size and anorthite content to those of plagioclase phenocrysts in the host granite (Table 5), so they are derived from the respective host granite.

In the xenoliths, the plagioclase composition varies from $\mathrm{An}_{7}$ to $\mathrm{An}_{27}$, but the zoning in each sample is weak, because the largest difference found in An content in each single crystal is only $7 \%$.

\subsection{Biotite}

They are generally $\mathrm{Fe}^{2+}$-biotites according to the nomenclature of Foster (1960), but Mg-biotite was also found in the core of a tonalitic enclave. Most of them correspond to biotites of igneous origin (Gokhale, 1968), but biotite from the core of tonalitic enclaves corresponds to a metamorphic-metasomatic biotite due to its enrichment in $\mathrm{Mg}$ which reflects that it did not equilibrate with biotite from host granite.

In the microgranular enclaves, the biotite of the core is richer in $\mathrm{Mg}$ and poorer in $\mathrm{Al}, \mathrm{Ti}$ and $\mathrm{Fe}^{2+} / \mathrm{Mg}$ than the biotite of the rim of the enclave (Fig. 9), showing that they retain some of the origi-

Table 5

Composition of feldspars of enclaves and host granites from Nelas area, central Portugal

*: The enclave with $\mathrm{An}_{41}$ has no phenocrysts. Analyst: M.M.V.G. Silva.

\begin{tabular}{|c|c|c|c|c|c|c|c|c|c|c|}
\hline & & \multicolumn{2}{|l|}{ Biotite } & \multirow{3}{*}{$\begin{array}{l}\text { Biotite- } \\
\text { muscovite }\end{array}$} & Tonalitic & \multicolumn{2}{|c|}{ Granodioritic } & \multirow{2}{*}{$\begin{array}{l}\text { Monzogra- } \\
\text { nitics }\end{array}$} & \multicolumn{2}{|c|}{ Xenoliths } \\
\hline & & \multicolumn{2}{|c|}{ granites } & & \multicolumn{5}{|l|}{ enclaves in } & \\
\hline & & & & & $\begin{array}{l}\text { biotite- } \\
\text { muscovite }\end{array}$ & biotite & $\begin{array}{l}\text { biotite- } \\
\text { muscovite } \\
\text { granites }\end{array}$ & $\begin{array}{l}\text { biotite } \\
\text { muscovite }\end{array}$ & biotite & $\begin{array}{l}\text { biotite } \\
\text { muscovite }\end{array}$ \\
\hline Orthoclase content & Phenocrysts & 64-94 & $73-96$ & & & & $85-95$ & & & \\
\hline of alkali feldspar & Matrix & $87-98$ & $86-99$ & $79-92$ & & $89-91$ & $86-96$ & $87-93$ & & $88-93$ \\
\hline Anorthite content & Phenocrysts & $18-39$ & & $22-56$ & $18-36$ & & $15-38$ & & & \\
\hline of plagioclase & $\begin{array}{l}\text { Matrix } \\
\text { Xenocrysts }\end{array}$ & $3-33$ & $2-31$ & $\begin{array}{l}18-50 \\
21-36\end{array}$ & $11-34$ & $14-33$ & $9-41^{*}$ & $1-31$ & $16-21$ & $7-27$ \\
\hline
\end{tabular}



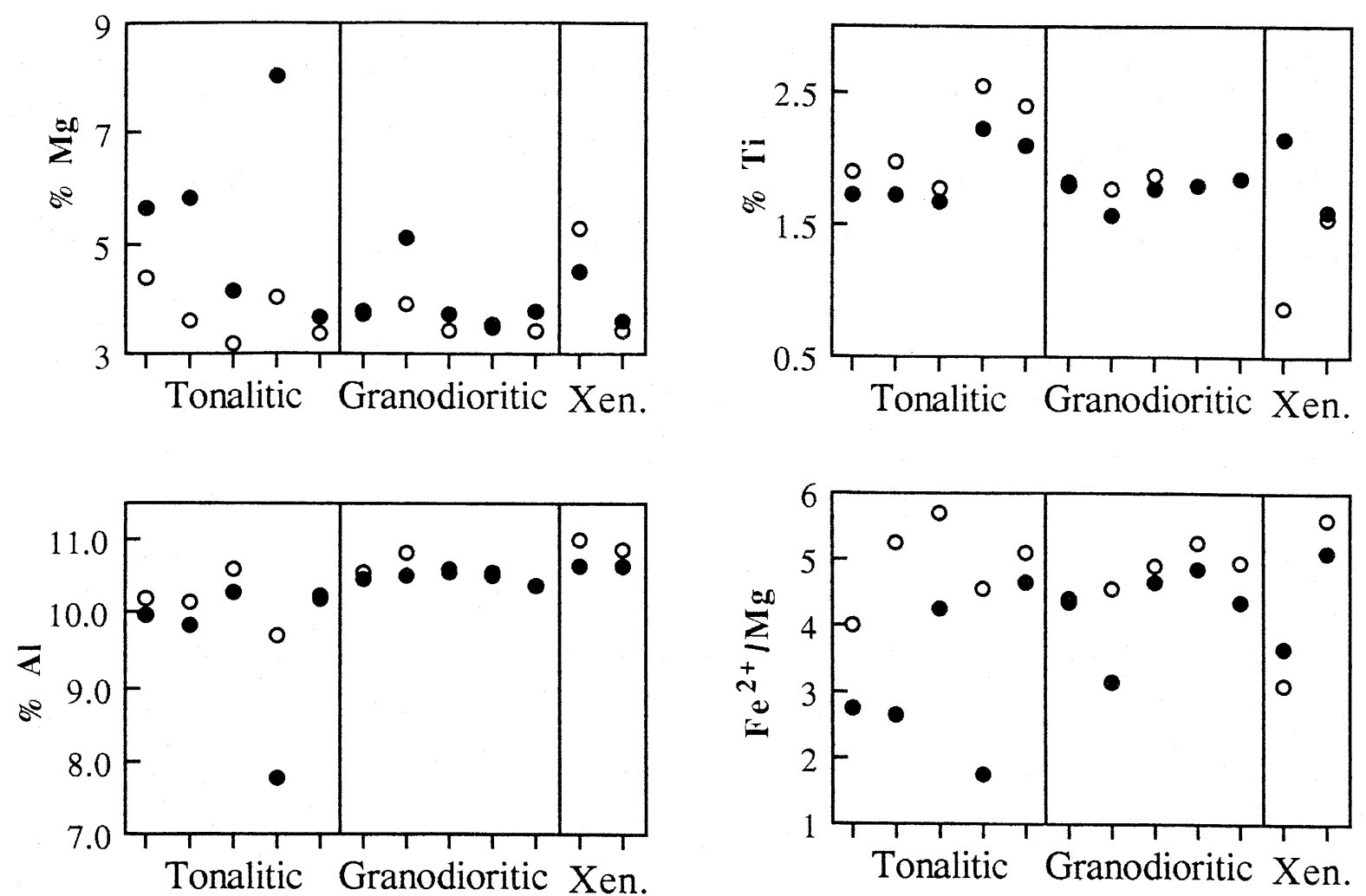

Fig. 9. Selected diagrams of biotite from core and rim of microgranular enclaves and xenoliths from Nelas, central Portugal. Symbols: core, $\bigcirc$ - rim.

nal compositional contrast, while in the xenoliths the biotite of the core is only richer in $\mathrm{Ti}$ and poorer in $\mathrm{Al}$ than the biotite of the rim.

\section{Discussion}

A general increase in $\mathrm{SiO}_{2}, \mathrm{~K}_{2} \mathrm{O}$ and decrease in $\mathrm{FeO}_{\mathrm{t}}, \mathrm{TiO}_{2}, \mathrm{MgO}, \mathrm{CaO}, \mathrm{V}$ (Fig. 4) and all REE (Fig. 6) was found from tonalitic to monzogranitic enclaves and the latter have a composition similar to that of the host granite. The anorthite content of plagioclase also decreases in this apparent sequence of enclaves. However, there is an increase in $\mathrm{Sr} / \mathrm{Ca}$ and decrease in $\mathrm{Rb} / \mathrm{K}$ from tonalitic to monzogranitic enclaves which generally have lower $\mathrm{Sr} / \mathrm{Ca}$, higher $\mathrm{Rb} / \mathrm{K}$ and similar $\mathrm{Rb}, \mathrm{Li}, \mathrm{Sr}, \mathrm{Ba}$ and $\mathrm{Li} / \mathrm{Mg}$ values to those of host granites (Fig. 4). So the microgranular enclaves do not represent autoliths.
Some tonalitic enclaves have lower initial ${ }^{87} \mathrm{Sr} /{ }^{86} \mathrm{Sr}$ and $\varepsilon \mathrm{Nd}$ than the respective host granite (Tables 3 and 4), which indicates that microgranular enclaves and host granites do not have a common origin.

The microgranular enclaves neither contain andalusite, sillimanite, cordierite, garnet nor residual minerals formed from mica dehydration. Furthermore, they have generally higher $\mathrm{Rb} / \mathrm{K}$ values (Fig. 4) and positive $\mathrm{Rb}$ and $\mathrm{Th}$ anomalies (Fig. 5) and there is no continuous variation in peraluminosity from enclaves to granites. So they do not represent restites.

There are several lines of evidence (e.g., enclaves have rounded or ovoid shape, contain acicular apatite and are finer-grained than host granite; contact morphologies such as phenocrysts of host granite partially enclosed in enclaves and host granite magma intruded enclaves) which strongly suggest that enclaves have been incorporated as magma globules into host granitic magma. Some enclaves contain 
quartz and plagioclase megacrysts of similar size and compositions to those of host granite plagioclase phenocrysts (Table 5), suggesting that they have been mechanically transferred from host granite magma to enclave magma.

The complex zoning of plagioclase phenocrysts in biotite granite, the almost linear trends of $\mathrm{SiO}_{2}$, $\mathrm{TiO}_{2}, \mathrm{MgO}, \mathrm{CaO},\left(\mathrm{Na}_{2} \mathrm{O}+\mathrm{K}_{2} \mathrm{O}\right), \mathrm{V}, \mathrm{Zn}, \mathrm{Sr} / \mathrm{Ca}$ and $\mathrm{Rb} / \mathrm{K}$ (Fig. 4) and Silva (1995) and the fact that granodioritic and monzogranitic enclaves have intermediate compositions between the tonalitic enclaves and the host granite suggest involvement of a mixing process (Barbarin and Didier, 1992). Rb, Li, Sr, Ba and $\mathrm{Li} / \mathrm{Mg}$ present scatter in the variation diagrams, which can be attributed to variation in the chemical composition of end members and small post-crystallization chemical changes (Neves and Vauchez, 1995).

The sequence of events would have been the following: (1) a biotite granite magma was intruded by a mafic magma. Microgranular enclaves were formed by a mingling/mixing process. The most contaminated biotite granite magma represented by its least silicic samples remained close to these enclaves. The least contaminated biotite granite magma represented by its most silicic samples does not contain enclave material. (2) The least contaminated biotite granite magma evolved and assimilated country metasedimentary rocks (AFC process) originating a biotite-muscovite granite magma. (3) This magma was intruded by another mafic magma. Microgranular enclaves were also formed by a mingling/mixing process. The most contaminated biotite-muscovite granite magma occurs close to the enclaves and is represented by the least silicic samples of this granite, while the least contaminated biotite-muscovite granite magma has no microgranular enclaves and is represented by its most silicic samples.

The binary mixing test of Fourcade and Allègre (1981) was applied, in the case of biotite granite, using the average composition of the most silicic samples to represent the least contaminated granite magma composition, while the least silicic tonalitic enclave in this granite represents the basic magma, because no mafic rocks were found exposed in the area. The percentage of $\mathrm{SiO}_{2}$ increases and those of $\mathrm{TiO}_{2}$, total $\mathrm{FeO}$ and $\mathrm{CaO}$ decrease versus the decrease in the weight fraction of tonalitic magma and the trends are linear (Fig. 10A). These relationships suggest that the least silicic samples of biotite granite contain about $20-25 \%$ by weight of tonalitic magma.

The variation diagrams (Fig. 4) and the REE patterns of granites (Fig. 6a) are compatible with a crystal fractionation model for the relationship between the two host granites. The large difference in $\left({ }^{87} \mathrm{Sr} /{ }^{86} \mathrm{Sr}\right)_{0}$ ratio between the two granites (Table 3 and Fig. 8) requires an AFC process. The assimilated country rock would have a composition similar to that of the Pre-Ordovician metapelitic-metagraywacke rocks with a high initial ${ }^{87} \mathrm{Sr} /{ }^{86} \mathrm{Sr}=0.73$. The fractionation of the liquid in relation to the initial mass of magma would have been 0.8 and the assimilation/fractionation ratio would be 0.3 (Silva and Neiva, in press).

The same mixing test was applied to the host biotite-muscovite granite and its microgranular enclaves. The average of the most silicic samples of this granite represents the least contaminated granite magma and the least silicic tonalitic enclave in this granite represents the tonalitic magma. Linear increase in the percentage of $\mathrm{SiO}_{2}$ and linear decrease in the percentages of $\mathrm{TiO}_{2}$, total $\mathrm{FeO}$ and $\mathrm{MgO}$ as a function of the decrease in the weight fraction of tonalitic magma was also found (Fig. 10B). The monzogranitic composition of enclaves could not be modelled, because it has a composition similar to that of the granite end member. The indicated weight fraction of tonalitic magma involved in the mixing in the case of the biotite-muscovite granite is $10-15 \%$. In both tests, the least silicic compositions of the host granite fits the respective linear trends, suggesting that it represents the contaminated granite magma.

Trace elements were also used to evaluate the mixing process. The proportions of tonalitic and granite magmas involved in the mixing are those calculated from major elements. The calculated and analysed contents of trace elements for granodioritic enclaves in each host granite show good agreement (Fig. 11a,b). However, this agreement is not so good for the least silicic composition of each host granite, because it is close to that of the respective granite end member.

A mafic magma intruded and mingled with the host granite magmas which were partially crystallized, because phenocrysts of host granite were transferred to microgranular enclaves as xenocrysts. Fast 
A
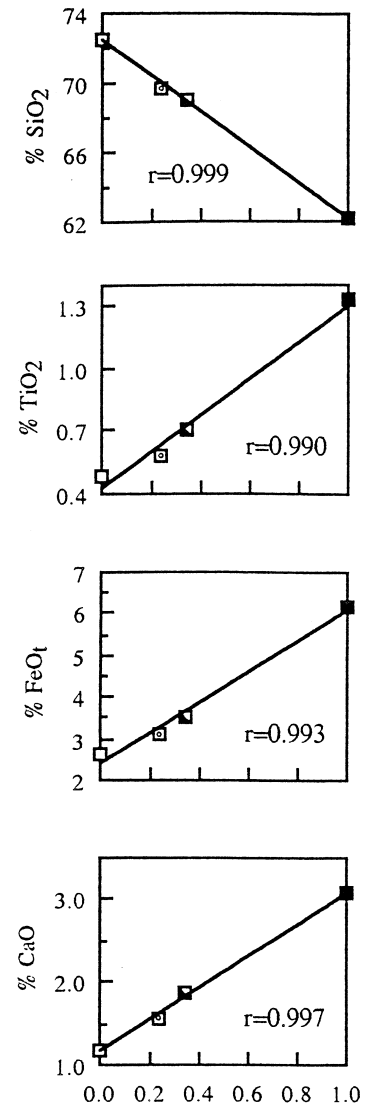

$\mathrm{T}$
B
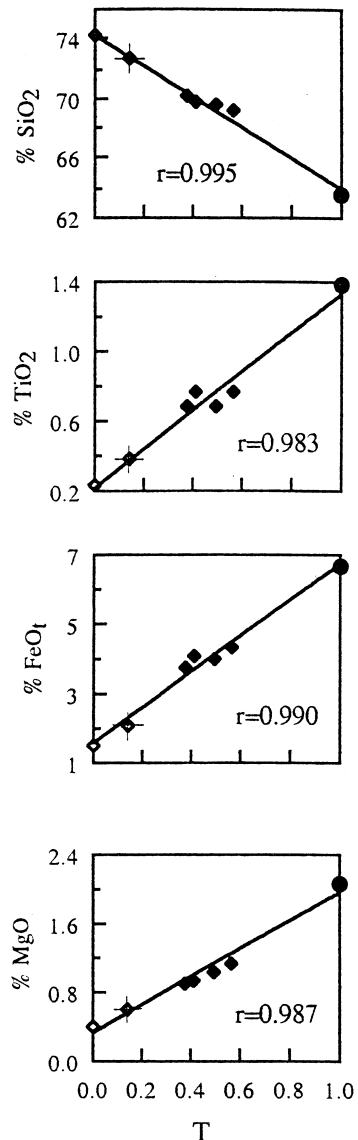

$\mathrm{T}$
Fig. 10. Plot of some analytical contents versus the weight fraction of tonalitic magma involved in the binary mixing process for microgranular enclaves and host granites from Central Portugal. (A) $\mathbf{\square}$ - tonalitic magma, $\mathbf{\Delta}$ - granodioritic enclaves, (square with small circle inside) - least silicic biotite granite composition, $\square-$ biotite granite magma. (B) - tonalitic magma, - granodioritic enclaves, (circle with cross) - least silicic biotite-muscovite granite composition, $\diamond-$ biotitemuscovite granite magma. T-weight fraction of tonalitic magma.

crystallization took place due to the thermal contrast and mechanical mixing was important in the origin of tonalitic enclaves. Thermal equilibrium was quickly reached (Barbarin and Didier, 1992) and favoured chemical mixing which predominated in the origin of other microgranular enclaves. However, differences in viscosity must have made difficult the chemical mixing. As all the microgranular enclaves studied are enriched in biotite, the mafic magma had a high water content which enabled it to remain liquid inside the granite magma and favoured chemical mixing (Grasset and Albarède, 1994). Biotite crystallized early during the fast cooling stage and was chemically re-equilibrated after the thermal equilibration, during the slow cooling stage of enclave magma inside the granite magma. Biotites from cores and rims of small tonalitic and granodioritic enclaves show some chemical differences (Fig. 9), suggesting that rims have more fully equilibrated with the host granite.

The generally similar isotopic signature (Fig. 8) in microgranular enclaves and respective host granite suggest that equilibrium was at least partially attained which probably changed the mineralogy and isotope geochemistry of all enclaves. However, these enclaves in the biotite granite have lower $\varepsilon_{\mathrm{Nd}}$ than that of the host granite (Fig. 8), so it is uncertain whether the composition of tonalitic enclaves represents the original mafic enclave magma or the partially equilibrated enclaves due to diffusional processes.
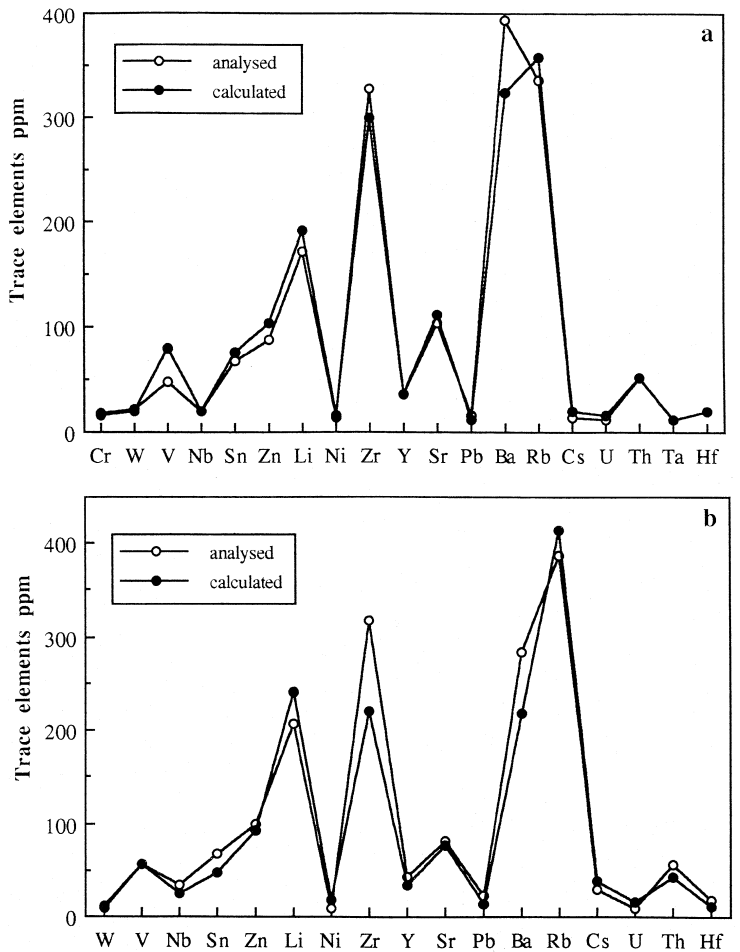

Fig. 11. Comparison of analyzed and calculated trace elements contents of granodioritic enclaves from Central Portugal. (a) In host biotite granite, (b) in host biotite-muscovite granite. 
The least silicic enclaves found in the biotitemuscovite granite are of tonalitic composition, but with a higher initial ${ }^{87} \mathrm{Sr} /{ }^{86} \mathrm{Sr}$ ratio than that of tonalitic enclaves found in the biotite granite (Table 3). So it is assumed that the biotite-muscovite granite magma was also intruded by a tonalitic magma. However, the isotopic signature of these enclaves and of host biotite-muscovite granite are similar which can be attributed to diffusional processes (Elburg, 1996). The hybridization of the biotitemuscovite granite was local and is represented by the transitional zone between both granites.

The intrusion of a mafic magma into the biotite granite magma took place at depth, because no mixing zones were found at emplacement level (Barbarin and Didier, 1992), but the biotite-muscovite granite magma was also intruded by another mafic magma during ascent because this granite contains a hybrid mixing zone where enclaves show sigmoidal shapes.

The initial ${ }^{87} \mathrm{Sr} /{ }^{86} \mathrm{Sr}$ ratio for the least silicic tonalitic enclave in the host biotite granite is low (0.7052) and the $\varepsilon_{\mathrm{Nd}}$ is negative (Fig. 8), which suggest that the tonalitic magma would have been derived from the enriched mantle.

\section{Conclusions}

(1) Peraluminous tonalitic, granodioritic and monzogranitic enclaves occur in the biotite granite and biotite-muscovite granite. They are mainly rounded or ovoid, commonly $20-50 \mathrm{~cm}$ in diameter, finergrained and richer in biotite and apatite than host granite. Their mineralogical association is similar to that of host granite. They contain xenocrysts of quartz and plagioclase of similar size and composition to plagioclase phenocrysts of host granite.

(2) $\mathrm{Rb}, \mathrm{Li}, \mathrm{Sr}, \mathrm{Ba}$ and $\mathrm{Li} / \mathrm{Mg}$ have similar values in all microgranular enclaves and host granites and $\mathrm{Sr} / \mathrm{Ca}$ increases and $\mathrm{Rb} / \mathrm{K}$ decreases from tonalitic to monzogranitic enclaves. $\mathrm{SiO}_{2}, \mathrm{TiO}_{2}, \mathrm{MgO}, \mathrm{CaO}$, $\left(\mathrm{Na}_{2} \mathrm{O}+\mathrm{K}_{2} \mathrm{O}\right), \mathrm{V}, \mathrm{Zn}, \mathrm{Sr} / \mathrm{Ca}$ and $\mathrm{Rb} / \mathrm{K}$ show linear trends.

(3) The microgranular enclaves generally have initial ${ }^{87} \mathrm{Sr} / 86 \mathrm{Sr}$ and $\varepsilon_{\mathrm{Nd}}$ similar to those of host granite.

(4) Biotites of cores from tonalitic and granodioritic enclaves have higher $\mathrm{Mg}$ content and lower $\mathrm{Ti}$,
$\mathrm{Al}$ and $\mathrm{Fe}^{2+} / \mathrm{Mg}$ contents than biotite of the respective rim.

(5) The major and trace element contents of granodioritic enclaves and contaminated granites can be modelled by simple mixing between a tonalitic magma and the host granite magma.

(6) Microgranular enclaves in both host granites result from the mixing of globules of basic magma with the host granite magma. The mechanical mixing was dominant in tonalitic enclaves, while chemical mixing predominated in granodioritic and monzogranitic enclaves. The biotite composition and isotopic signature of microgranular enclaves and respective host granite suggest subsequent partial equilibration of these enclaves.

(7) Xenoliths are generally $<10 \mathrm{~cm}$ long, showing sharp contact with the host granite. Two petrographic types were distinguished, but they have similar mineralogical and chemical compositions. They contain higher $\mathrm{Rb}$ and $\mathrm{Cs}$ contents and initial ${ }^{87} \mathrm{Sr} /{ }^{86}$ $\mathrm{Sr}$ ratios than those of microgranular enclaves and host granites.

\section{Acknowledgements}

This paper corresponds to part of the Ph.D. of M.M.V.G. Silva. Thanks are due to Dr. J. Esson for $\mathrm{XRF}$ and microprobe facilities in the Department of Earth Sciences, University of Manchester, UK; Dr. S.J. Parry for the facilities at the Nuclear Reactor, Ascot, UK; R. Goodwin (University of Oxford) assisted with isotope separators. Funding was provided to M.M.V.G. Silva by a grant from I.N.I.C., Portugal. This research was carried out in the programme of Geosciences Centre, University of Coimbra. This paper benefited from the helpful comments of two anonymous referees.

\section{References}

Barbarin, B., Didier, J., 1992. Genesis and evolution of mafic microgranular enclaves through various types of interaction between coexisting felsic and mafic magmas. Trans. R. Soc. Edinburgh: Earth Sci. 83, 145-153.

Beetsma, J.J., 1995. The late Proterozoic/Paleozoic and Hercynian crustal evolution of the Iberian Massif, Northern Portugal. Unpublished Ph.D. thesis, Faculty of Earth Sciences, Vrije Universiteit, Amsterdam, p. 233. 
Brown, G.C., Hughes, D.J., Esson, J., 1973. New XRF data retrieval techniques and their applications to USGS standard rocks. Chem. Geol. 11, 223-229.

Chappell, B.W., White, A.J.R., Wyborn, D., 1987. The importance of residual source material (restite) in granite petrogenesis. J. Petrol. 28, 1111-1138.

Chen, Y.D., Price, R.C., White, A.J.R., 1989. Inclusions in three S-type granites from Southeastern Australia. J. Petrol. 30, 1181-1218.

Cocherie, A., Rossi, Ph., Fouillac, A.M., Vidal, Ph., 1994. Crust and mantle contributions to granite genesis - An example from the Variscan batholith of Corsica, France, studied by trace-element and $\mathrm{Nd}-\mathrm{Sr}-\mathrm{O}$-isotope systematics. Chem. Geol. $115,173-211$.

Debon, F., Le Fort, P., 1982. A chemical-mineralogical classification of common plutonic rocks and associations. Trans. R. Soc. Edinburgh: Earth Sci. 73, 135-149.

De Paolo, D.J., 1981. Neodymium isotopes in the Colorado Front Range and crust-mantle evolution in the Proterozoic. Nature (London) 291, 193-196.

Dias, G., Leterrier, J., 1994. The genesis of felsic-mafic plutonic associations: a $\mathrm{Sr}$ and $\mathrm{Nd}$ isotopic study of the Hercynian Braga Granitoid Massif, Northern Portugal. Lithos 32, $207-$ 223.

Didier, J., Barbarin, B., 1991. Enclaves and Granite Petrology. Developments in Petrology, Vol. 13. Elsevier, Amsterdam.

Dodge, F.C.W., Kistler, R.W., 1990. Some additional observations on inclusions in the granitic rocks of the Sierra Nevada. J. Geophys. Res. 95, 17841-17848.

Elburg, M.A., 1996. Evidence of isotopic equilibration between microgranitoid enclaves and host granodiorite, Warburton Granodiorite, Lachlan Fold Belt, Australia. Lithos 38, 1-22.

Ferreira, N., Iglesias, M., Noronha, F., Pereira, E., Ribeiro, A., Ribeiro, M.L., 1987. Granitóides da Zona Centro Ibérica e seu enquadramento geodinâmico. In: Bea, F., Carnicero, A., Gonzalo, J.C., López Plaza, M., Rodrigues Alonso, M.D. (Eds.), Geologia de los Granitoides y Rocas Asociadas del Macizo Hespérico. Ed. Rueda, Madrid, pp. 37-51.

Foster, M.D., 1960. Interpretation of the composition of trioctahedrical micas. U.S. Geol. Surv. Prof. paper 354-B, pp. 1-49.

Fourcade, S., Allègre, C.J., 1981. Trace element behavior in granitic genesis: a case study, the calc-alkaline plutonic association from the Querigut Complex, Pyrénées, France. Contrib. Mineral. Petrol. 76, 177-195.

Fourcade, S., Javoy, M., 1991. Sr-Nd-O isotopic features of mafic microgranular enclaves and host granitoids from the Pyrenees, France: evidence for their hybrid nature and inference on their origin. In: Didier, J., Barbarin, B. (Eds.), Enclaves and Granite Petrology. Elsevier, Amsterdam, pp. 345366.

Gokhale, N.W., 1968. Chemical composition of biotites as a guide to ascertain the origin of granites. Bull. Geol. Soc. Finl. 40, $107-111$.

Grasset, O., Albarède, F., 1994. Hybridization of mingling magmas with different densities. Earth Planet. Sci. Lett. 121, $327-332$.
Haskin, L.A., Haskin, M.A., Frey, F.A., Wildeman, T.R., 1968. Relative and absolute terrestrial abundances of the rare earths. In: Ahrens, L.H. (Ed.), Origin and Distribution of the Rare Elements, Vol. 1. Pergamon, Oxford, pp. 889-911.

Hibbard, M.J., 1991. Textural anatomy of twelve magma-mixed granitoid systems. In: Didier, J., Barbarin, B. (Eds.), Enclaves and Granite Petrology. Elsevier, Amsterdam, pp. 431-444.

Jacobsen, S.B., Wasserburg, G.J., 1984. Sm-Nd isotopic evolution of chondrites and achondrites, II. Earth Planet. Sci. Lett. 67, 137-150.

Le Bas, M.J., Streckeisen, A.L., 1991. The IUGS systematics of igneous rocks. J. Geol. Soc. (London) 148, 825-833.

Maas, R., Nicholls, I.A., Legg, C., 1997. Igneous and metamorphic enclaves in the S-type Deddick Granodiorite, Lachlan Fold Belt, SE Australia: petrographic, geochemical and Nd-Sr isotopic evidence for crustal melting and magma mixing. J. Petrol. 38, 815-841.

Matte, Ph., 1986. La châine varisque parmi les châines paléozoiques péri atlantiques, modèle d'évolution et position des grands blocs continentaux au Permo-Carbonifère. Bull. Soc. Géol. Fr. 2, 9-24.

Miller, C.F., Stoddard, E.F., Bradfish, L.J., Pollase, W.A., 1981 Composition of plutonic muscovite: genetic implications. Can. Mineral. 19, 25-34.

Neves, S.P., Vauchez, A., 1995. Successive mixing and mingling of magmas in plutonic complex of Northeast Brazil. Lithos 34, 275-299.

Noronha, F., Ramos, J.M.F., Rebelo, J.A., Ribeiro, A., Ribeiro, M.L., 1979. Essai de corrélation des phases de déformation hercynienne dans le Nord-Ouest Péninsulaire. Bol. Soc. Geol. Port. 21, 227-237.

Pearce, J.A., Harris, N.B.W., Tindle, A.G., 1984. Trace element discrimination diagrams for the tectonic interpretation of granitic rocks. J. Petrol. 25, 956-983.

Pereira, E., Ribeiro, A., Meireles, C., 1993. Cisalhamentos hercínicos e controlo das mineralizações de $\mathrm{Sn}-\mathrm{W}$, Au e U na Zona Centro-Ibérica. Cuad. Lab. Xeol. Laxe 18, 89-119.

Silva, M.M.V.G, 1995. Mineralogia, petrologia e geoquímica de encraves de rochas graníticas de algumas regiões portuguesas. Unpublished Ph.D. thesis, Faculdade de Ciências e Tecnologia, Universidade de Coimbra, p. 288.

Silva, M.M.V.G, Neiva, A.M.R., in press. Geochemistry of Hercynian peraluminous granites and their minerals from Carregal do Sal-Nelas-Lagares da Beia, central Portugal.

Stephens, W.E., Holden, P., Henney, P.J., 1991. Microdioritic enclaves within the Scottish Caledonian granitoids and their significance for crustal magmatism. In: Didier, J., Barbarin, B. (Eds.), Enclaves and Granite Petrology. Elsevier, Amsterdam, pp. $125-134$.

Whitehouse, M.J., 1990. Isotopic evolution of the southern Outer Hebridean Lewisian gneiss complex: Constraints on Late Archaean source regions and the generation of transposed $\mathrm{Pb}-\mathrm{Pb}$ palaeoisochrons. Chem. Geol. (Isotope Geoscience Section) $86,1-20$

Wyllie, P.J., Cox, K.G., Biggar, G.M., 1962. The habit of apatite in synthetic systems and igneous rocks. J. Petrol. 3, 238-243. 